\title{
Juvenile gout
}

\author{
BLAIR L. J. TREADWELL \\ From the Rheumatology Unit, Wellington Hospital, Wellington, New Zealand
}

The rarity of gout in children prompts the following report of two cases, both apparently 'primary' in nature. On occasion juvenile gout may result from a demonstrable cause, falling into the 'secondary' category. In secondary gout both blood and urinary levels of uric acid tend to be higher than in primary gout, and the ratio of renal clearance of uric acid to glomerular filtration rate is usually increased. The miscible pool of uric acid and its rate of turnover are also increased.

Gout and aleukaemic leukaemia in a boy aged 5 years was described by Vining and Thomson (1934), this being the first description of the association of gout and leukaemia in a child. It is of interest that there was a positive family history of gout in this case. Kersley, Mandel, and Jeffrey (1950) reported the case of a male who suffered the onset of gout when aged 18 years and died aged 23. Talbott (1959) considers this case also to be one of myeloid metaplasia. Other blood disorders reported as causing juvenile gout include congenital haemolytic anaemia (Lambie, 1940; Deitrick, 1940), both authors describing 14-year-old boys, and secondary polycythaemia with congenital heart disease (Somerville, 1961). Absence of glucose-6-phosphatase activity in glycogen storage disease of the von Gierke type causes hyperlacticacidaemia from glycogenolysis with renal retention of urate. Gout commencing at the age of 14 years in this condition was described by Jeune, Charrat, and Bertrand (1957) and probably yby Smythe and Cutchin (1962) in a male aged 16 oears. Lesch and Nyhan (1964) described a syndrome f hyperuricaemia, mental retardation, choreothetosis, and self-destructive biting in two brothers ged 5 and 8 years, and a number of other such cases have since been documented (Hoefnagel, Andrew, Mireault, and Berndt, 1965; Nyhan, Oliver, and Lesch, 1965; Reed and Fish, 1966; Shapiro, Sheppard, Dreifuss, and Newcombe, 1966).

Catel and Schmidt (1959) described the case of a $2 \frac{1}{2}$-year-old boy with choreoathetosis, mental retardation, and hyperuricaemia without azotaemia.
There was a family history of mental retardation, gout, and renal disease. A similar case of a boy aged 3 years with gout and cerebral palsy with athetosis is discussed by Riley (1960). It is likely that both these patients suffered from the Lesch-Nyhan syndrome, a sex-linked disorder which has been shown to be due to a congenital absence of hypoxanthineguanine phosphoribosyltransferase, an enzyme participating in purine metabolism (Seegmiller, Rosenbloom, and Kelley, 1967).

A literature survey of the subject of 'primary' juvenile gout has revealed 66 cases in addition to those discussed above where the 'secondary' nature of the gout is more or less established. In 22 instances, however, insufficient detail is supplied, particularly in relation to age and sex (Table I).

Table I References in which insufficient detail is supplied of cases said to be examples of juvenile gout

\begin{tabular}{|c|c|c|c|c|}
\hline Authors & Date & No. of cases & Sex & Age (yrs) \\
\hline Morgagni & 1769 & 2 & Male & 15 \\
\hline Gairdner & 1849 & 2 & Female & 'Young' \\
\hline Strandgaard & 1899 & 7 & & $11-20$ \\
\hline Futcher & 1907 & 2 & & $11-20$ \\
\hline Cohen & 1936 & 4 & & $10-20$ \\
\hline $\begin{array}{l}\text { Brøchner- } \\
\text { Mortensen }\end{array}$ & 1941 & 2 & & $17-20$ \\
\hline $\begin{array}{l}\text { McCracken and } \\
\text { others }\end{array}$ & 1946 & 1 & & 19 \\
\hline $\begin{array}{l}\text { Weiss and } \\
\text { Segaloff }\end{array}$ & 1959 & 1 & & 6 \\
\hline $\begin{array}{l}\text { Spanopoulos } \\
\text { (1960), quoting } \\
\text { Trousseau }\end{array}$ & 1 & & & 7 \\
\hline
\end{tabular}

The earliest and most extensive description is that of Scudamore (1823). His patients included individual males aged $8,12,16$, and 17 at the time of the first 
episode of gout, four aged 18, three aged 19, two females aged 15, and one female aged 18. Gairdner (1849) discussed the case of a girl aged 11 at the time of her first attack. There was a positive family history of gout. The patient herself 'died at an early age after much distressing sickness from chorea and hysteria'. Garrod (1876) described two males aged 9 and 16 at the time of the first attack, and two females, both aged 7. Duckworth (1889) mentioned the case of a male aged 50 who suffered his first attack at the age of 11 .

References in the 20th century, describing males, with the patient's age at onset of gout in square brackets, include: Mayer von Schopf (1930) [5 wks]; Berk (1948) [11]; Flinchum and Powers (1951) [15]; Hartleib (1954) [18]; Cameron (1955) [12]; Combined Staff Clinical Conference of the National Institutes of Health (1957) [16]; Davison (1958) [15]; Decker and Vandeman (1962) [16]; Talbott (1964) [6]. Single case reports of females are: Still (1924) a girl of 12 years who suffered her first attack of gout at the age of $3 \frac{1}{2}$ years; Claiborne (1940) [14]; Rauch (1950) a 23-year-old female who developed gout in the hands at the age of $3 \frac{1}{2}$ years; Recht (1954) a 27 -year-old woman who had suffered acute gout from the age of 5; Coodley (1958) [11].

Multiple case reports include those of Bernstein (1947) - two males aged 14 and 16, and two females aged 12 and 16; Cohen (1948)-two negro brothers both aged 12 at onset; Duncan and Dixon (1960)two brothers aged 14 and 15; Rosenthal, Gaballah, and Rafelson (1961) - two males aged 2 mths and 15 yrs. In Table II the number of cases, age at onset, and sex are summarized and grouped in decades.

\section{Present investigations}

Case 1, a 37-year-old part-Maori woman, first presented in July, 1966, with a history of recurrent acute gout since the age of 8 years. The first metatarsophalangeal joints had been solely affected until 1 year previously when the ankles had become involved. Initially attacks had been spaced years apart but recently the incidence had been monthly. Early and subsequent attacks were typical of acute gout, arising spontaneously overnight, with redness, swelling, pain, and marked tenderness of the affected joint, responding to colchicine and settling completely between episodes. She was normotensive.
Family history

The patient's family history is unusual. Her parents are half-siblings. Her sole grandfather, aged 100, had had nine wives. Two of his children of different mothers married each other, not knowing initially of their close relationship (Fig. 1). Offspring of this union total four, one of whom is the patient. There is no family history of gout.

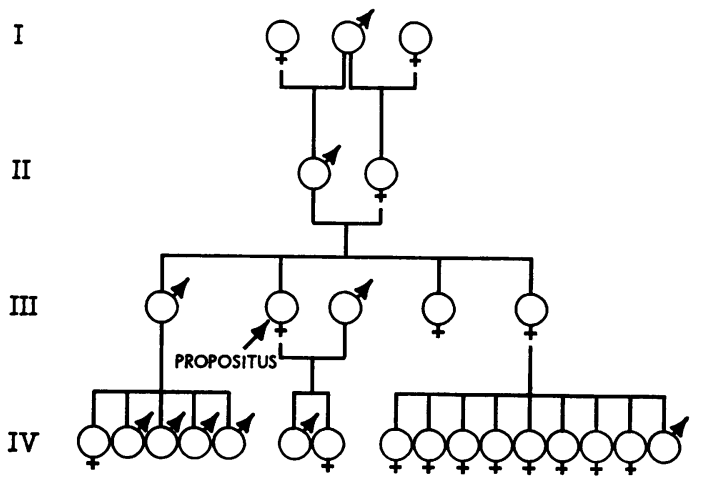

FIG. 1. Family tree of Case 1.

\section{Laboratory investigations}

Serum urate 8.0 and $7.5 \mathrm{mg} . / 100 \mathrm{ml}$. (normal up to $6.5 \mathrm{mg}$. $/ 100 \mathrm{ml}$. for women); erythrocyte sedimentation rate 29 and $4 \mathrm{~mm} . / 1 \mathrm{hr}$ (Wintrobe); Hb 9.9 and 11.5 g./100 ml.; rheumatoid factor negative (latex fixation); serum sodium $142 \mathrm{mEq}$./1.; serum potassium $4.3 \mathrm{mEq}$./1.; serum chloride $108 \mathrm{mEq} . / 1$.; urea 59 and $42 \mathrm{mg} . / 100 \mathrm{ml}$.; creatinine clearance $57 \mathrm{ml} . / \mathrm{min}$.; 24-hour proteinuria $427 \mathrm{mg}$.; uric acid clearance $4.6 \mathrm{ml}$./min.

Pyelography showed kidneys measuring $12 \mathrm{~cm}$. in their long axes, with some irregularity of outline of the lower pole on the right.

Radiography of the feet outlined cystic changes in the heads of both first metatarsals (Fig. 2, opposite).

On renal biopsy periglomerular fibrosis was defined with dilatation of tubules and collecting ducts, thickening of arterial walls, and interstitial infiltration with lymphocytes and plasma cells. The histology suggested chronic pyelonephritis.

\section{Treatment}

Treatment with probenecid was instituted.

Table II Summary of the literature survey of 'primary' juvenile gout, illustrating numbers of cases, sex, and age at onset of gout

\begin{tabular}{|c|c|c|c|c|c|c|c|c|c|c|c|c|c|c|c|c|c|c|c|c|c|c|}
\hline \multirow{3}{*}{$\begin{array}{l}\text { Decade } \\
\text { Age (yrs) }\end{array}$} & \multicolumn{11}{|c|}{ First } & \multicolumn{11}{|c|}{ Second } \\
\hline & \multicolumn{10}{|c|}{ Number of cases } & \multirow[t]{2}{*}{ Total } & \multicolumn{10}{|c|}{ Number of cases } & \multirow[t]{2}{*}{ Total } \\
\hline & 0 & 1 & 2 & 3 & 4 & 5 & 6 & 7 & 8 & 9 & & 10 & 11 & 12 & 13 & 14 & 15 & 16 & 17 & 18 & 19 & \\
\hline Male & 2 & 0 & 0 & 0 & 0 & 0 & 1 & $\mathbf{0}$ & 1 & 1 & 5 & 0 & 2 & 4 & 0 & 2 & 4 & 5 & 1 & 5 & 3 & 26 \\
\hline Female & $\mathbf{0}$ & 0 & 0 & 2 & 0 & 1 & 0 & 2 & 0 & 0 & 5 & 0 & 2 & 1 & 0 & 1 & 2 & 1 & 0 & 1 & 0 & 8 \\
\hline
\end{tabular}




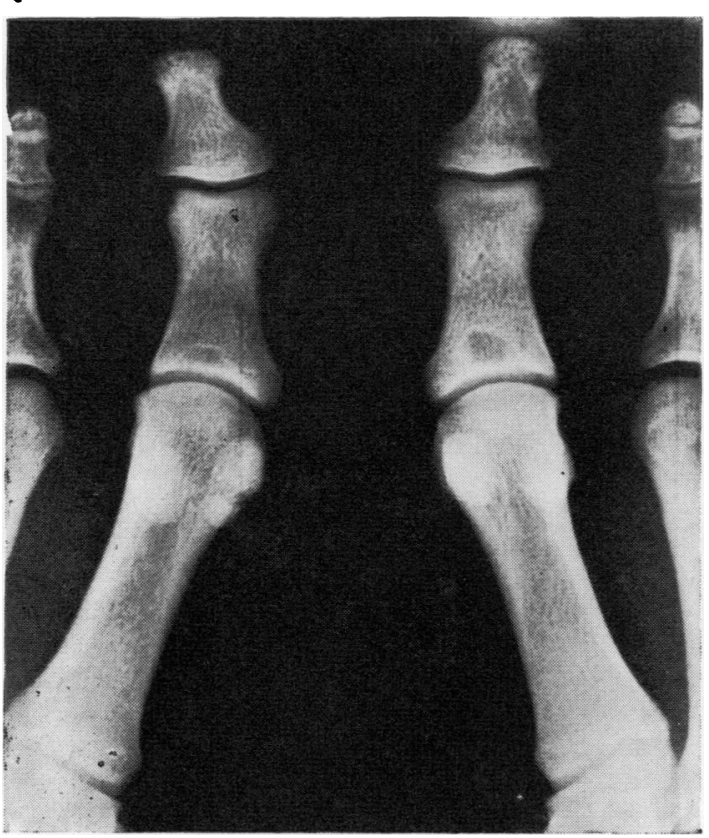

FIG. 2. Radiographs of first metatarsal joints of Case 1.

Laboratory findings 2 months later

Serum urate $5.4 \mathrm{mg} . / 100 \mathrm{ml}$.; erythrocyte sedimentation rate $24 \mathrm{~mm}$./1 hr (Wintrobe); Hb $11.9 \mathrm{~g} . / 100 \mathrm{ml}$.; urea $36 \mathrm{mg} . / 100 \mathrm{ml}$; creatinine clearance $76 \mathrm{ml} . / \mathrm{min}$.; 24-hour proteinuria $312 \mathrm{mg}$; uric acid clearance $7 \cdot 1$ $\mathrm{ml} . / \mathrm{min}$.

4-hrly urinary pH over a 24-hr period revealed an absence of diurnal rhythm, the $\mathrm{pH}$ varying between $5 \cdot 1$ and $5 \cdot 25$.

Case 2, a female adolescent of European-Lebanese extraction, was first investigated in December, 1966, at the age of 15 . When aged 13 years she suffered her first attack of acute arthritis of the first metatarsophalangeal joint. She gave a classical history of severe pain in the affected joint overnight, marked tenderness even to the lightest touch, and inability to bear weight on the affected foot. One attack was observed in hospital, the joint being swollen and very tender, with the overlying skin warm, reddened, and dry. Approximately seven acute episodes had occurred over a 14-month period culminating in her first admission to hospital in December, 1966. Without treatment each attack had lasted 1 to 2 weeks, but response to phenylbutazone was prompt, symptoms subsiding in 1 to 3 days.

\section{Family history}

There was a positive family history of gout affecting two male first cousins on the maternal side (Fig. 3). The mother's serum urate was $4.6 \mathrm{mg}$. $/ 100 \mathrm{ml}$., with a blood urea of $41 \mathrm{mg} . / 100 \mathrm{ml}$. The father's serum urate was $6.8 \mathrm{mg}$. $/ 100 \mathrm{ml}$. (normal up to $7.5 \mathrm{mg} . / 100 \mathrm{ml}$. for men), his blood urea being $30 \mathrm{mg}$. $/ 100 \mathrm{ml}$. There was no history of gout amongst the father's six siblings, and, as all were Roman Catholic priests or nuns, they had no issue. The serum urate of two of the patient's brothers and a sister was $7 \cdot 4,6 \cdot 0$, and $5 \cdot 3 \mathrm{mg} . / 100 \mathrm{ml}$. respectively, and their blood urea 21,29 , and $24 \mathrm{mg}$. $/ 100 \mathrm{ml}$. respectively.

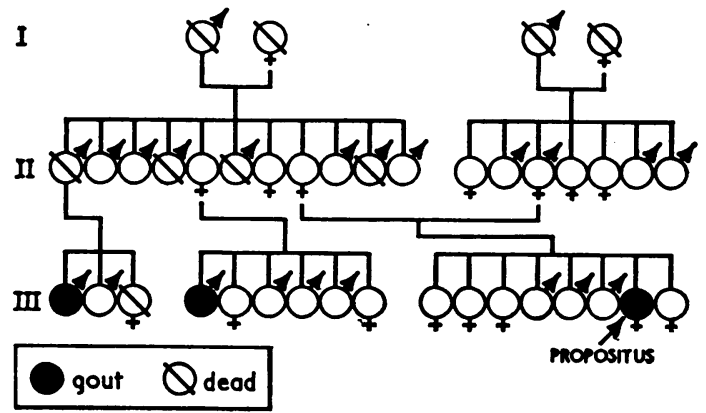

FIG. 3. Family tree of Case 2.

\section{Laboratory investigations}

Serum urate $10.8 \mathrm{mg} . / 100 \mathrm{ml}$., blood urea $83 \mathrm{mg} . / 100 \mathrm{ml}$., creatinine clearance 22 and $33 \mathrm{ml}$./min.

Serial results of renal function tests showed relatively little significant change (Table III).

On renal biopsy an inadequate sample was obtained. This showed a patchy interstitial infiltrate consisting

Table III Serial investigational data from Case 2. Intervening serum uric acid levels were, in general, within the normal range

\begin{tabular}{|c|c|c|c|c|c|c|c|}
\hline Date & Dec., 1966 & Feb., 1967 & Sept., 1967 & May, 1968 & May, 1969 & Feb., 1970 & May, 1970 \\
\hline Serum uric acid (mg./100 ml.) & $10 \cdot 8$ & $7 \cdot 7$ & $6 \cdot 2$ & $4 \cdot 6$ & $9 \cdot 0$ & $5 \cdot 6$ & $12 \cdot 6$ \\
\hline Serum urea $(\mathrm{mg} . / 100 \mathrm{ml})$. & 82 & 98 & 85 & 123 & 101 & 114 & 86 \\
\hline Uric acid clearance (ml./min.) & $1 \cdot 4$ & $1 \cdot 2$ & $1 \cdot 56$ & & $2 \cdot 6$ & & \\
\hline $\begin{array}{l}\text { Creatinine clearance } \\
\quad(\mathrm{ml} . / \mathrm{min} .)\end{array}$ & 33 & 52 & 42 & & 44 & & \\
\hline 24-hour proteinuria (mg.) & 300 & 400 & 750 & & 860 & & \\
\hline Urinary pH & $5 \cdot 5$ & $5 \cdot 0$ & $5 \cdot 0$ & & $5 \cdot 5$ & & \\
\hline $\begin{array}{l}\text { Significant urinary colony } \\
\text { counts }\end{array}$ & coliforms & nil & nil & & nil & & \\
\hline
\end{tabular}


mainly of lymphocytes and occasional plasma cells with some periglomerular fibrosis.

Drip-infusion pyelography did not reveal any definite abnormality of the urinary collecting system, and no reflux was deomonstrated on micturating cystourethrography. The urinary amino acids were normal, and the urine protein fractions similar to those in the serum.

\section{Progress}

Treatment with allopurinol was initiated in December, 1966, and has been continued to date. On the whole, satisfactory control of the hyperuricaemia has been maintained, although some increase in dosage has been necessary, and the patient has at times been unreliable with drug taking.

\section{Discussion}

Inevitably there was some lack of precision in early accounts. The clinical criteria for the diagnosis of acute gout were ill-defined, and the physicians of the day had no ancillary aids. Even today misdiagnosis of gout is all too frequent owing, at least in part, to undue reliance on investigational results with too little attention to clinical features. Garrod (1876), recognizing the problem of misdiagnosis of gout, wrote (p. 213): ‘. . instances are related in which gout is said to have occurred in very young children, but I am of opinion that in many of these cases considerable doubt may te entertained as to the correctness of the diagnosis, for in young subjects other joint affections, such as rheumatism, and more especially rheumatoid arthritis, may readily be mistaken for gout.' Sixty years before Garrod, Scudamore (1816) had discussed the same problem, and wrote of the rarity of juvenile gout: 'The exemption of youth from the gout is a striking character of the disease. I am persuaded that the commonly-asserted cases, which represent the existence of the gout in early youth, are really examples of rheumatism. Some gouty persons have given me confident assurances that their first fit took place at fifteen; and one gentleman declares, at seven years of age. I am sceptical as to the accuracy of these statements, although I will not deny the probability of an exception to the general rule, in the occurrence of the gout between the fifteenth and twentieth year; but at an earlier period it would ke a singular phenomenon.' In a later edition of his monograph Scudamore (1823) does in fact describe two cases, both male, cccurring before the age of 15 .

Morgagni (1769), quoting Brasavolus, briefly refers to '. . . two illustrious young men of fifteen years of age, who began to labour under the gout ...' and Gairdner (1849) mentions two 'young girls' with gout. Spanopoulos(1960) refers to a case described by Trousseau in a child of 6 . In view of the inexactitude of these references it seems wise to regard them with $\frac{1}{5}$ caution. An account by Claiborne (1940) of a 17- $\square$ year-old girl with intermittent arthritis of the right knee for 3 years leaves considerable doubt concerning $\vec{\Rightarrow}$ the diagnosis, although the case has been included $\stackrel{?}{+}$ in the foregoing literature survey.

The sex incidence is of interest. In a series of $116 \frac{\overline{\bar{s}}}{\frac{5}{4}}$ cases of gout, none below the age of 20, Williamson $\triangle$ (1920) found less than 1 per cent. to be female. Brøchner-Mortensen (1941), amongst 100 gouty patients, two of whom were below the age of 21, records a female incidence of 3 per cent. McCracken, $\vec{\omega}$ Owen, and Pratt (1946), in a further series of $100 \stackrel{\omega}{\omega}$ cases of gout, one being less than 20 years of age (19), found nine women with gout. They quoted reports $\hat{\omega}$ in the then recent literature totalling 1,484 cases, $\underset{\omega}{\omega}$ where the female incidence was 6.6 per cent. Kuzell, it Schaffarzick, Naugler, Koets, Mankle, Brown, and 0 Champlin (1955), on the other hand, described a 을 series of 520 patients, 26 per cent. of whom were female. This seems to te an unusually high incicence, $\vec{z}$ but only 9 per cent. of the females $(12$ cases) were below the age of 40 years.

The literature of juvenile gout, however, discloses a male : female ratio in the first decade of $5: 5$, or 7 $5: 6$ when Case 1 of the present report is included. Assessment of the incidence in the second decade is complicated by insufficient information in 22 cases. If these are excluded, the male : female ratio is $\stackrel{\square}{\mathbb{Q}}$ $26: 8$, or $26: 9$ including Case 2 of this report. $\overrightarrow{\overrightarrow{0}}$ This proportion of females- 55 per cent. in the first $\frac{\text { O }}{3}$ decade and 26 per cent. in the second decade-is thus much higher than the incidence found in adult series, even including that of Kuzell and others (1955) if allowance is made for age.

We have learnt much from the elucidation of the Lesch-Nyhan syndrcme and Seegmiller's work tracing the enzyme defect. Here is an example of a specific enzyme deficit, sex-linked to the male, 음 resulting in over-producticn of uric acid. It is tempting to spcculate on the possitility of further enzyme defects without sex-linkage to explain the equal sex incidence in the first decace, and the or relatively large proportion of females in the second $N$ decade when compared with the incidence found in adults.

A number of gouty children have developed renalo disease at an early stage, and may already be azotaemic when first seen (Duncan and Dixon, 1960; $\stackrel{?}{\rightarrow}$ Davison, 1958), including Case 2 of this report. The $\frac{T}{0}$ possibility of the renal disease teing respcnsible for $\frac{\vec{D}}{\mathbb{D}}$ the hyperuricaemia should be considered, but $\stackrel{\oplus}{\oplus}$ alternatively these children could be suffering from $\stackrel{\mathbb{Q}}{\varrho}$ gouty nephropathy or a congenital defect of renal $\bar{\sigma}$ function including urate retention. The uric acid $ᄋ$ 
clearance in Case 2 is consistent with both the first and the last hypothesis.

A strong family history of gout is common in juvenile cases, many authors recording a series of affected relatives (Gairdner, 1849; Garrod, 1876; Still, 1924; Bernstein, 1947; Coodley, 1958; Rosenthal and others, 1961). Morgagni (1769) wrote: 'I myself have seen little children, who were seized with severe pains of the joints, and greatly disordered thereby, before they had well got out of their infant state: and have at the same time known that their father, grandfather, and greatgrandfather had been subject to the gout.' Furthermore, it is not unusual to find the family history positive on both sides. Three of the four patients reported by Garrod (1876) c ome into this category. The patient of Rosenthal and others (1961), a 19-month-old boy, had been hyperuricaemic and uraemic from the age of 2 months, although actual gout is not mentioned. The father was hyperuricaemic, the maternal grandmother had gout, and a 15-year-old half-brother by another father had hyperuricaemia, joint disease, and urinary calculi. Three sons and one daughter of the family described by Duncan and Dixon (1960) developed gout (personal communication), the remaining daughter having died of renal disease. Both parents were hyperuricaemic though not gouty.
It becomes increasingly apparent that gout is a collection of diseases. The term 'primary gout' is really a misnomer, although useful at the present time. It is probably fair to say that an increasing proportion of patients will develop gout which proves to be secondary to a more basic disorder. This trend is particularly probable in children and adolescents with the development of knowledge of enzyme defects. The careful assessment of juvenile gout is therefore of particular importance, as each and every case may throw light on the various causes of gout as a whole.

\section{Summary}

Two cases of females with juvenile gout developing at ages 8 and 13 years are described. Evidence of renal disease is recorded in both instances. Old and recent literature on the subject of juvenile gout is reviewed, indicating a total of 66 cases of apparent 'primary' gout. In only 44 , however, are details of sex and age at onset supplied. The male to female ratio is $5: 6$ in the first decade, and $26: 9$ in the second decade, the incidence of juvenile gout in the female being strikingly greater than that found in adult series.

\section{References}

BERK, M. E. (1948) Amer. J. med. Sci., 215, 290 (Gout: report of an unusual case in a young man).

Bernstein, S. S. (1947) J. Mt Sinai Hosp., 14, 747 (Gout in early life).

BRøCHNER-MORTENSEN, K. (1941) Acta med. scand., 106, 81 (100 gouty patients).

Cameron, M. G. P. (1955) Canad. med. Ass. J., 72, 205 (Chronic tophaceous gout).

CATEl, W., AND SchmidT, J. (1959) Dtsch. med. Wschr., 84, 2145 (On familial gouty diathesis associated with cerebral and renal symptoms in a small child-in German).

Claiborne, T. S. (1940) J. Amer. med. Ass., 115, 38 (Gout in a seventeen-year-old girl).

COHEN, A. (1936) Amer. J. med. Sci., 192, 488 (Gout). (1948) Amer. J. Med., 4, 911 (Gout in a negro family).

Combined Staff Clinical Conference of National Institutes of Health (1957) Ibid., 22,807 (Metabolic and clinical aspects of gout).

CoOdley, E. (1958) Calif. Med., 88, 375 (Atypical manifestations of gout).

Davison, K. (1958) Postgrad. med. J., 34, 651 (Tophaceous gout in a seventeen-year-old male).

Decker, J. L., ANd Vandeman, P. R. (1962) Amer. J. Med., 32, 805 (Renal calculi preceding gouty arthritis in a child).

Deitrick, J. E. (1940) New int. Clin., n.s. 3, 264 (The association of congenital hemolytic icterus and gout).

Duckworth, D. (1889) 'A Treatise on Gout', p. 326. Griffin, London.

Duncan, H., ANd Dixon, A. St. J. (1960) Quart. J. Med., 29, 127 (Gout, familial hyperuricaemia, and renal disease).

FlinCHUM, D., AND Powers, J. A. (1951) N.C. med. J., 12, 433 (Gout in young people).

Futcher, T. B. (1907) 'Gout', in 'A System of Medicine', ed. W. Osler and T. McCrae, vol. 1, p. 809. Hodder and Stoughton, London.

GaIRDNER, W. (1849) 'On Gout; its History, its Causes, and its Cure', pp. 151-152. Churchill, London.

GarroD, A. B. (1876) 'A Treatise on Gout and Rheumatic Gout', 3rd ed., p. 215. Longmans Green, London.

Hartleib, J. (1954) Z bl. allg. Path., 92, 198 (Über einen ungewöhnlichen Fall von Gicht bei einem 18 jährigen Mann).

Hoefnagel, D., Andrew, E. D., Mireault, N. G., and Berndt, W. O. (1965) New Engl. J. Med., 273,130 (Hereditary choreoathetosis, self-mutilation and hyperuricemia in young males).

Jeune, M., Charrat, A., And Bertrand, J. (1957) Arch. franç. Pédiat., 14, 897 (Polycorie hépatique, hyperuricémie et goutte). 
Kersley, G. D., Mandel, L., AND Jeffrey, M. R. (1950) Ann. rheum. Dis., 9, 282 (Gout, an unusual case with softening and subluxation of the first cervical vertebra and splenomegaly).

Kuzell, W. C., Schaffarzick, R. W., Naugler, W. E., Koets, P., Mankle, E. A., Brown, B., and Champlin, B. (1955) J. chron. Dis., 2, 645 (Some observations on 620 gouty patients).

Lambie, C. G. (1940) Med. J. Aust., 1, 535 (A study of juvenile gout in a patient suffering from chronic erythronoclastic anaemia of obscure origin, together with observations upon the physical state of uric acid in the blood and the effects of splenectomy).

Lesch, M., AND Nyhan, W. L. (1964) Amer. J. Med., 36, 561 (A familial disorder of uric acid metabolism and central nervous system function).

McCracken, J. P., Owen, P. S., ANd Pratt, J. H. (1946) J. Amer. med. Ass., 131, 367 (Gout: still a forgotten disease).

MAYeR voN SChOPf, E. (1930) Klin. Wschr., 9, 2148 (Gicht bei einem 5 wochen alten Säugling).

MorgagnI, J. B. (1769) 'The Seats and Causes of Diseases', vol. 3, p. 324. Millar, London.

NyHAN, W. L., Oliver, W. J., AND LeSCh, M. (1965) J. Pediat., 67, 257 (A familial disorder of uric acid metabolism and central nervous system function II).

RaUCh, H. W. M. (1950) Med. Mschr., 4, 931 (Gicht bei einem $3 \frac{1}{2}$ jährigen Mädchen).

RECHT, L. (1954) Acta med. scand., 150, 189 (A case of severe gout in a woman aged 27).

ReEd, W. B., AND Fish, C. H. (1966) Arch. Derm. (Chicago), 94, 194 (Hyperuricemia with self-mutilation and choreo-athetosis).

RiLEY, I. D. (1960) Arch. Dis. Childh., 35, 293 (Gout and cerebral palsy in a three-year-old boy).

Rosenthal, I. M., Gaballah, S., and Rafelson, M. (1961) Amer. J. Dis. Child., 102, 631 (Metabolic studies in a young child with elevated serum uric acid levels).

ScudAmORe, C. (1816) 'A Treatise on the Nature and Cure of Gout', p. 45. Longman, Hurst, Rees, Orme, and Brown, London.

- (1823) 'A Treatise on the Nature and Cure of Gout and Gravel', 4th ed., pp. 57-63. Longman, Hurst, Rees, Orme, and Brown, London.

Seegmiller, J. E., Rosenbloom, F. M., And Kelley, W. N. (1967) Science, 155, 1682 (Enzyme defect associated with a sex-linked human neurological disorder and excessive purine synthesis).

Shapiro, S. L., Sheppard, G. L., Dreifuss, F. E., AND Newcombe, D. S. (1966) Proc. Soc. exp. Biol. (N.Y.), 122, 609 (X-linked recessive inheritance of a syndrome of mental retardation with hyperuricemia).

Smythe, C. M., AND Cutchin, J. H. (1962) Amer. J. Med., 32, 799 (Primary juvenile gout).

SOMERVILL, J. (1961) Brit. Heart J., 23, 31 (Gout in cyanotic congenital heart disease).

Spanopoulos, G. (1960) Practitioner, 185, 674 (A case of gout in a teenager).

STILL, G. F. (1924) 'Common Disorders and Diseases of Childhood', 4th ed., p. 525. Oxford University Press, London.

StrandGaARD, N. J. (1899) 'Gigt og urinsur diatese’. København.

TALBOTt, J. H. (1959) Medicine (Baltimore), 38, 173 (Gout and blood dyscrasias). (1964) 'Gout', 2nd ed., p. 26. Grune and Stratton, New York.

Vining, C. W., AND Thomson, J. G. (1934) Arch. Dis. Childh., 9, 277 (Gout and aleukaemic leukaemia in a boy aged five).

Weiss, T. E., AND SEgaloff, A. (1959) 'Gouty Arthritis and Gout', p. 13. Thomas, Springfield, Ill.

Williamson, C. S. (1920) J. Amer. med. Ass., 74, 1625 (Gout: a clinical study of one hundred and sixteen cases). 